\title{
COMPARISON OF HOMOGENIZATION APPROACHES USED FOR THE IDENTIFICATION OF THE MATERIAL PARAMETERS OF UNIDIRECTIONAL COMPOSITES
}

\author{
PRIMERJAVA HOMOGENIZACIJSKIH PRIBLIŽKOV ZA \\ UGOTAVLJANJE PARAMETROV MATERIALA ENOSMERNIH \\ KOMPOZITOV
}

\author{
Hana Srbová, Tomáš Kroupa, Vladimír Lukeš \\ University of West Bohemia in Pilsen, NTIS - New Technologies for the Information Society, Univerzitní 22, 306 14, Plzeň, Czech Republic \\ hsrbova@kme.zcu.cz
}

Prejem rokopisa - received: 2015-07-01; sprejem za objavo - accepted for publication: 2016-06-06

doi:10.17222/mit.2015.177

\begin{abstract}
The paper is aimed at the identification of the material parameters of the constituents of unidirectional long-fiber carbon/epoxy composites. The ratios between the real fiber and the matrix volume of unidirectional fiber composites were identified from the images obtained with scanning electron microscopy (SEM). Fiber and matrix areas were analyzed using Matlab and its image-processing toolbox. Determined volume ratios were used to propose the geometry of a micromechanical representative volume element. An algorithm ensuring an irregular fiber distribution in the representative volume element cross-section and periodicity in the cross-section plane were used. A single-layer representative volume element with a mesh was built in Abaqus/CAE. Experimentally obtained force-elongation dependencies for the tensile tests of the specimens with different fiber orientations were processed and effective moduli were determined. In the first approach, the material parameters of phases were identified using the OptiSlang optimization software and finite-element code Abaqus. A periodically constrained representative volume element was loaded according to the experiments where specimens with different fiber orientations were loaded by tensile force. In the second approach, the SfePy software and asymptotic homogenization were used for the numerical computation on the microscopic scale, resulting in the homogenized material parameters that were afterwards used at the macroscopic level. The optimization function characterized the sum of the differences of the effective moduli and the difference of Poisson's ratios of the whole composite.
\end{abstract}

Keywords: composite, unidirectional, micro-model, constituents, material parameters, cross-section, homogenization

Namen članka je ugotavljanje materialnih parametrov sestavin epoksi kompozitov z enosmernim dolgimi ogljikovimi vlakni. Razmerje realnih vlaken in volumna osnove kompozitov z usmerjenimi vlakni je bilo določeno iz slik, dobljenih na vrstičnem elektronskem mikroskopu (SEM). Vlakna in področja osnove so bili analizirani s pomočjo Matlaba in njegovega orodja za obdelavo slik. Določena volumska razmerja so bila uporabljena za predlog geometrije reprezentativnih mikromehanskih volumskih elementov. Uporabljen je bil algoritem, ki zagotavlja neenakomerno razporeditev vlaken na preseku reprezentativnega volumskega elementa in periodičnost na ravnini preseka. Plast reprezentativnega volumskega elementa $\mathrm{z}$ mrežo, je bila postavljena z Abaqus/CAE. Izvedeni so bili eksperimenti za določanje odvisnosti sila-raztezek pri nateznih preizkušancih z različno orientacijo vlaken in določeni so bili efektivni moduli. V prvem približku so bili ugotavljani materialni parametri faz s pomočjo OptiSlang programske opreme za optimizacijo in kodo končnih elementov Abaqus. Periodično omejen reprezentančni volumski element je bil obremenjen, skladno s preizkusi. Pri čemer so bili vzorci z različno orientacijo vlaken, obremenjeni z natezno silo. Pri drugem približku je uporabljena programska oprema SfePy in asimptotična homogenizacija, za numerične izračune na mikroskopskem nivoju, kar se je odrazilo $\mathrm{v}$ homogenih parametrih materiala, ki so bili kasneje uporabljeni na makroskopskem nivoju. Optimizacijska funkcija je karakterizirana z vsoto razlik efektivnega modula in razliko Poissonovega razmerja za celoten kompozit.

Ključne besede: kompozit, enosmernost, mikromodel, sestavine, parametri materiala, presek, homogenizacija

\section{INTRODUCTION}

The experiments are the main tools and play a dominant role in the characterization of mechanical behavior of materials. ${ }^{1-4}$ Nevertheless, in some cases, it is advantageous to support experimental measurements with the knowledge of the behavior of the considered material at the micro- or meso-scale level (low scale). ${ }^{5-7}$ A precisely calibrated low-scale model can be helpful in the cases where all the necessary material parameters for a macro-scale model are impossible to be characterized or in the case when the initiation or propagation of the processes observed on the micro-scale are not clear.
Anisotropy and heterogeneity of the inner structure and homogeneity of virtual macro-scale models of composite materials call for low-scale-model processing. The presented paper is aimed at a comparison of two methodologies for the identification of the material parameters of the substituents of unidirectional carbon-epoxy composites. There are several different approaches for homogenization and low-scale modelling, the presented paper deals with two of these. The first approach uses the advantages of commercial software Abaqus 6.14-2 and its wide range of pre- and post-processing tools including the possibility of an automatic model construction using the Python software. ${ }^{5}$ The second approach uses 
H. SRBOVÁ: COMPARISON OF HOMOGENIZATION APPROACHES USED FOR THE IDENTIFICATION ...

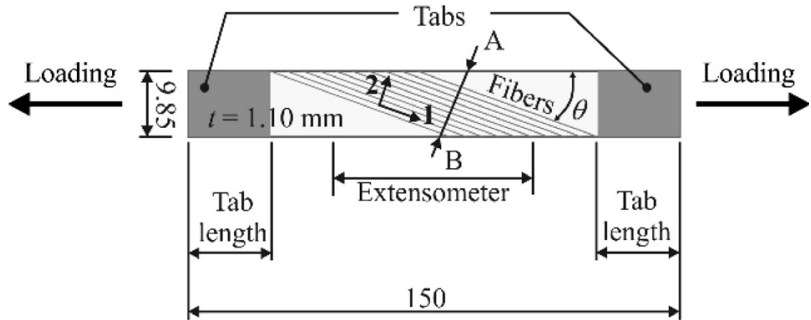

Figure 1: Geometry of coupons (mm), the cross-section (A-B) Slika 1: Geometrija kuponov (mm), presek A-B)

the well established theory of asymptotic homogenization, ${ }^{6,7}$ which is implemented in the SfePy finite-element software. ${ }^{8-10}$

\section{SPECIMENS AND THE EXPERIMENTAL PART}

Carbon-epoxy unidirectional continuous-fiber composite coupons were subjected to tensile loading. Rectangular specimens (coupons) were cut by a waterjet from a composite plate made of eight equally oriented layers, the so-called prepregs with $40 \%$ of epoxy HexPly 913C with fiber Tenax HTS 5631 cured for 120 minutes at a temperature of $125{ }^{\circ} \mathrm{C}$ and a pressure of 6 bar. There were 5 specimens tested for each of the following fiber orientations $(10,20,30,40,50,60,70$, 80 and 90$)^{\circ}$ with respect to the loading direction. Only two specimens were successfully tested up to the allowable type of rupture with fiber orientation $0^{\circ}$.

Force-elongation dependencies were obtained using a Zwick Roell/Z050 test machine where force values were estimated by a force cell and the gage area elongation was measured using a uniaxial macro-extensometer. The tested coupons with glass textile $\left(0^{\circ}\right)$ or aluminum tabs $(10,20,30,40,50,60)^{\circ}$ were bonded with high-strength and tough epoxy adhesive Spabond 345. In the case of the specimens with fiber orientations $(70,80 \text { and } 90)^{\circ}$ a non-bonded emery cloth was used as the interface bet-

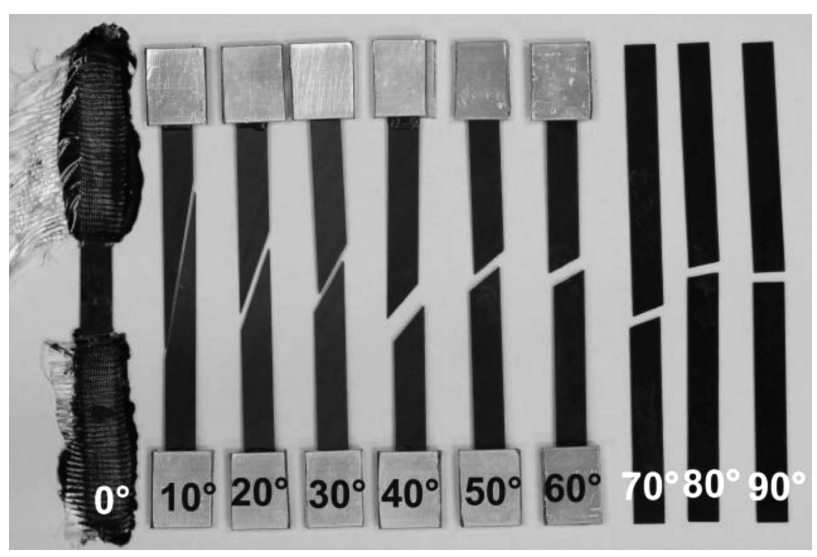

Figure 2: Cracked specimens, the final crack direction is parallel to the fibers for directions $10^{\circ}-90^{\circ}$ and perpendicular for direction $0^{\circ}$ Slika 2: Porušeni vzorci, usmeritev končne razpoke je vzporedna $\mathrm{z}$ vlakni za smeri $10^{\circ}-90^{\circ}$ in pravokotna za smer $0^{\circ}$ ween the grip and the coupon. The tab configuration summarized in Table $\mathbf{1}$ led to the required gage-section tensile failure (Figure 2).

Table 1: Experiment configuration

Tabela 1: Konfiguracija preizkusov

\begin{tabular}{|c|c|c|c|}
\hline $\begin{array}{c}\text { Fiber } \\
\text { orientation }\left(^{\circ}\right)\end{array}$ & Tab material & $\begin{array}{c}\text { Tab length } \\
(\mathrm{mm})\end{array}$ & $\begin{array}{c}\text { Extensometer } \\
\text { length }(\mathrm{mm})\end{array}$ \\
\hline 0 & glass textile & 60.0 & 10.0 \\
\hline $\begin{array}{c}10,20,30,40, \\
50,60\end{array}$ & aluminum & 25.0 & 60.0 \\
\hline $70,80,90$ & emery cloth & 25.0 & 60.0 \\
\hline
\end{tabular}

\section{IDENTIFICATION}

Two linear material models were supposed to be calibrated using a combination of finite-element analyses, optimization methods and experiments. ${ }^{11,12}$ The targets for the identification process were calculated from the experimental results before the identification process in Python began. The nominal stress was calculated from the applied tensile force $F$ as:

$$
\sigma=\frac{F}{A}
$$

where $A$ is the cross-section of a non-loaded specimen. The strain was calculated as

$$
\varepsilon=\frac{F}{A}
$$

Where $\Delta l$ is the elongation of the gage area (between the arms of the extensometer) and $l$ is the original gage length.
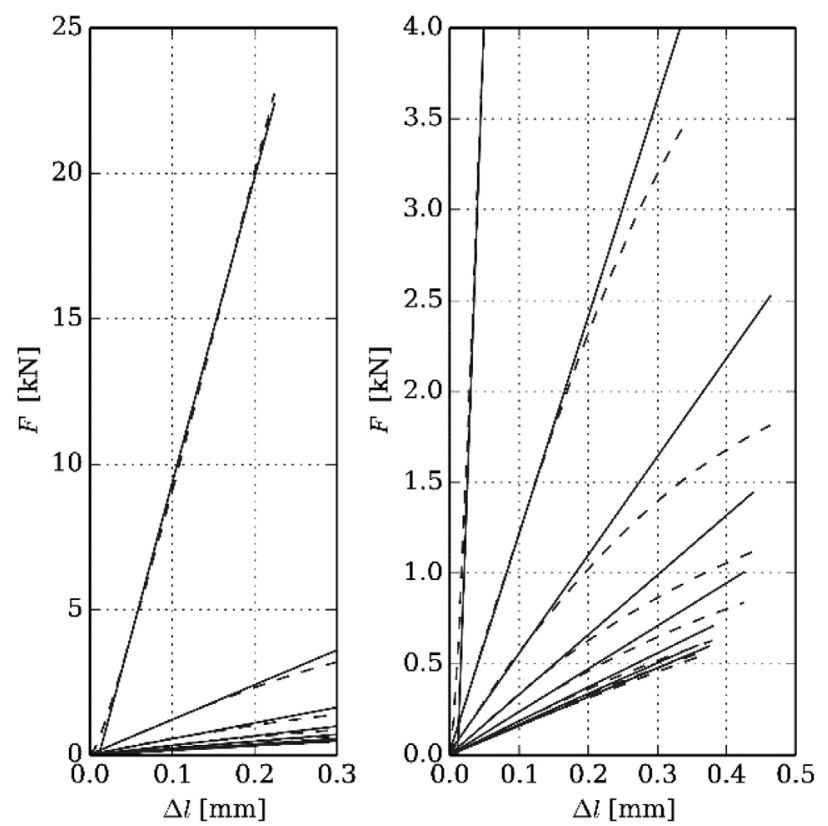

Figure 3: Tensile dependencies (dashed lines) and calculated targets for further identification (solid lines)

Slika 3: Natezne odvisnosti (črtkana linija) in izračunani cilji za nadaljnjo identifikacijo (polna črta) 
The target for each tensile test was calculated as least-squares fit of the straight line through the interval of the nominal strain $\langle 0,0.25 \%\rangle$ in the case of the concave dependency of force on elongation (Figure 3). The only exceptions are the experimental results with $0^{\circ}$ direction of the fibers where the target was calculated as least-squares fit of the straight line through the whole force-elongation dependency (Figure 3). The results for $0^{\circ}$ fiber orientation are influenced by the uncertainties caused by the penetration of the glass textile by the jaws of the machine at the beginning of the measurement (the loading process).

The tangents $k^{\mathrm{E}}$ of the fitted straight lines in the force-elongation diagram for each fiber orientation were taken as the values to be achieved in the numerical model. The only additional condition, which should be met in the model, is that Poisson's ratio $v_{12}^{C}$ of the whole composite should be as close as possible to the value of 0.28 (the measured value and the value obtained from the manufacturer). The residual function $r$ to be minimized in the identification processes, regardless of the used homogenization approach (homogenization using the commercial software Abaqus or asymptotic homogenization performed in SfePy), has the following form:

$$
r=\sum_{\theta}\left(1-\frac{k^{\mathrm{N}}(\theta)}{k^{\mathrm{E}}(\theta)}\right)^{2}+\left(1-\frac{v_{12}^{C}}{0.28}\right)^{2}
$$

Where $\theta$ is the fiber angle (the type of specimen) and $k^{\mathrm{N}}$ is the tangent of the numerically obtained results (Figure 3). Gradient algorithms implemented in the OptiSLang and Python software were used for the identification. ${ }^{12}$

\section{CREATING A REPRESENTATIVE UNIT CELL}

The representative volume element with a random distribution of fibers was built with an event-driven algorithm for simulating chaotically colliding billiard balls ${ }^{13}$ in Matlab. Each component (a fiber in this case) moves along a straight line until it collides with another component. Events (collisions) are processed in a non-

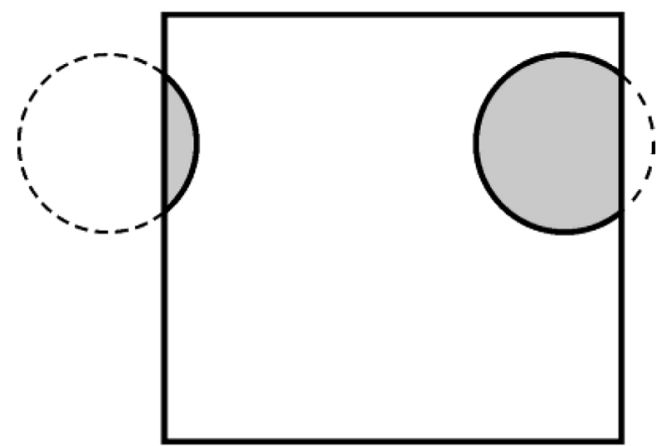

Figure 4: Parts of the fiber at the area boundaries in accordance with periodic boundary conditions

Slika 4: Deli vlakna na področju mej v skladu s pogoji periodičnosti meje decreasing order of time and interactions are scheduled using pre-integrated equations of the evolutions of the components. In the case of a uniform-component distribution, the evolution space is subdivided into small sectors so that only the components in the neighboring sectors have to be checked to determine the immediate collision and the time for processing the expected event is reduced. The defined fiber volume fraction is ensured with the termination criterion controlled by an increase in the volume fraction of the components. ${ }^{14}$

Periodicity of the volume element is ensured by a component disappearing at a boundary and reappearing at the opposite side (Figure 4).

The calculation of the fiber volume fraction was performed in the Matlab software. Digital images obtained with scanning electron microscopy (SEM) were analyzed (Figure 5) and the identified fiber volume fraction of the composite material is $V_{\mathrm{f}}^{\text {image }}=0.59$ The average fiber radius was identified as $R_{\mathrm{f}}=6.488 \mu \mathrm{m}$. The rectangular area with 15 fibers and dimensions of $28.7334 \times 28.7334 \mu \mathrm{m}$ was discretized in Abaqus/CAE by hexahedral 8 -node linear isoparametric elements and wedge 6-node linear isoparametric elements (Figures 5 and 7).

The finite-element mesh was built with only one layer of elements in the fiber direction. The fiber direction and loading direction are shown in Figure 6.

\section{MATERIAL MODELS}

The infinitesimal strain theory was considered when proposing the material models. The material model of fibers was linear, transversely isotropic and the behavior in the plane perpendicular to the fiber axis was considered to be isotropic. Five material parameters define this type of material. A material model of the matrix was proposed to be linear isotropic with two parameters necessary for the description of its behavior. The material model can be written in the matrix form as
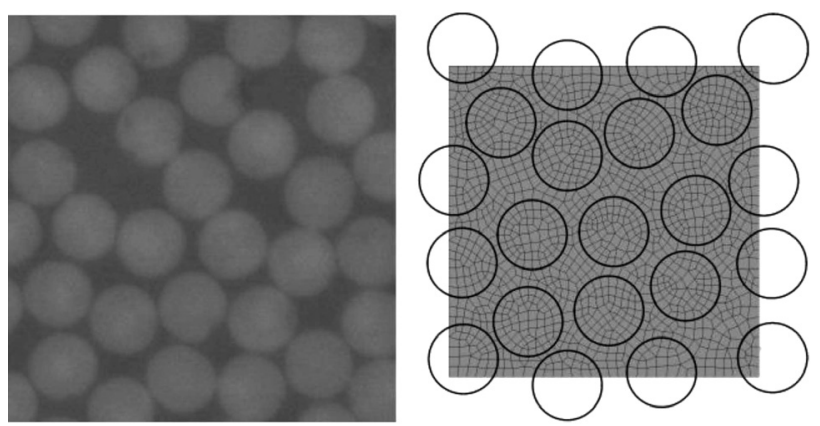

Figure 5: Image of cross-section (A-B) of unidirectional long fiber composite obtained with SEM (left) and unit cell with generated finite elements (right) and depicted fiber edges (black circles)

Slika 5: SEM-posnetek preseka (A-B) enosmernih dolgih vlaken v kompozitu (levo) in enotna celica z ustvarjenimi končnimi elementi (desno) in prikaz robov vlakna (črni krogi) 
H. SRBOVÁ: COMPARISON OF HOMOGENIZATION APPROACHES USED FOR THE IDENTIFICATION ...

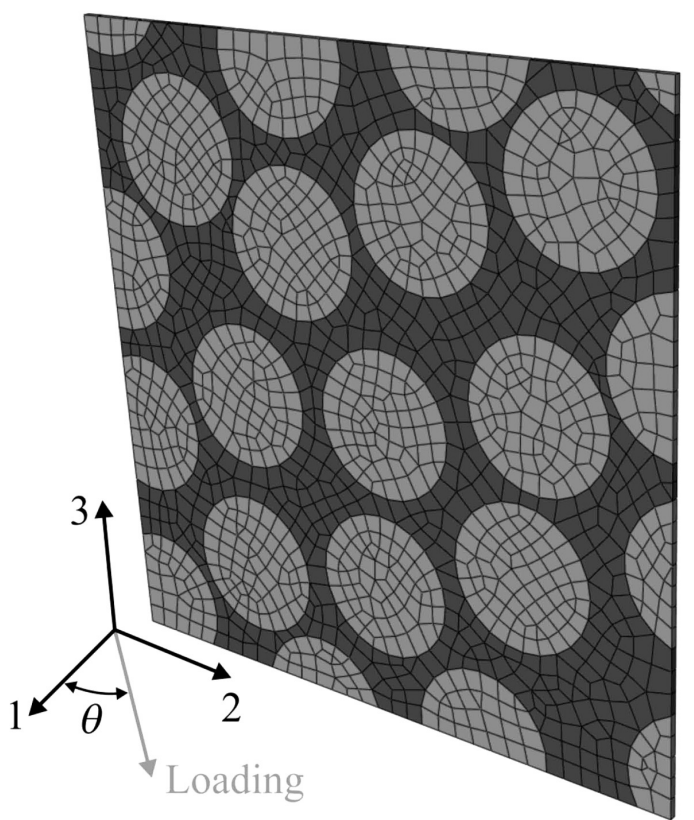

Figure 6: Material principal and loading-force directions Slika 6: Glavni material in smeri sile obremenitve

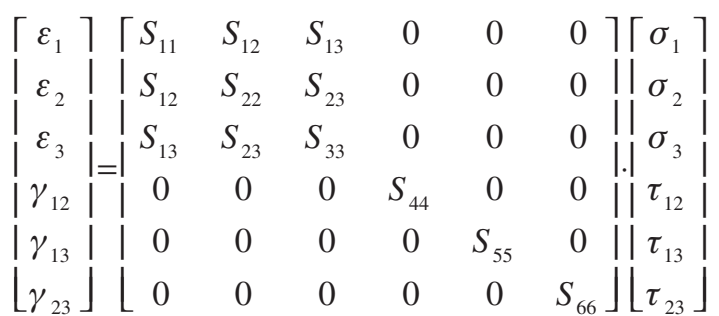

Where $\varepsilon_{i}$ is the normal engineering strain in direction $i, \gamma_{i j}$ is the engineering shear strain in the $i j$ plane, all being the elements of the strain tensor $\varepsilon, \sigma_{i}$ is the normal stress in direction $i$ and $\tau_{i j}$ is the shear stress in the $i j$ plane, all being the elements of the stress tensor $\sigma$. The elements of the compliance matrix $\mathrm{S}$, the elasticity tensor in the inverse shape, are, in the case of isotropic material, as follows in Equation (4):

$$
\begin{aligned}
& S_{11}=S_{22}=S_{33}=\frac{1}{E} \\
& S_{12}=S_{13}=S_{23}=-\frac{v}{E} \\
& S_{44}=S_{55}=S_{66}=\frac{E}{2(1+v)}
\end{aligned}
$$

and in the case of transversely isotropic material in Equation (5):

$$
\begin{gathered}
S_{11}=\frac{1}{E_{1}} \quad S_{22}=S_{33}=\frac{1}{E_{2}} \\
S_{12}=S_{13}=-\frac{v_{12}}{E_{1}} \quad S_{23}=-\frac{v_{23}}{E_{2}} \\
S_{44}=S_{55}=\frac{1}{G_{12}} \quad S_{66}=\frac{2\left(1+v_{23}\right)}{E_{2}}
\end{gathered}
$$

\begin{tabular}{|c|c|c|}
\hline Constant & Unit & Meaning \\
\hline \multicolumn{3}{|r|}{ Fibers } \\
\hline$E_{1}$ & $(\mathrm{~Pa})$ & Young's modulus in the axis direction \\
\hline$E_{2}$ & $(\mathrm{~Pa})$ & Young's modulus in the radial direction \\
\hline$v_{12}$ & $(-)$ & $\begin{array}{l}\text { Poisson's ratio in the planes parallel to } \\
\text { the fiber axis }\end{array}$ \\
\hline$v_{23}$ & $(-)$ & $\begin{array}{l}\text { Poisson's ratio in the planes perpendi- } \\
\text { cular to the fiber axis. This parameter } \\
\text { was defined by the manufacturer. }\end{array}$ \\
\hline$G_{12}$ & $(\mathrm{~Pa})$ & $\begin{array}{l}\text { Shear modulus in the planes parallel to } \\
\text { the axis of the fiber }\end{array}$ \\
\hline \multicolumn{3}{|r|}{ Matrix } \\
\hline$E$ & $(\mathrm{~Pa})$ & Young's modulus \\
\hline$v$ & $(-)$ & Poisson's ratio \\
\hline
\end{tabular}

The meanings of the material constants (parameters) of the models mentioned above are given in Table 2 .

Table 2: Description of material constants

Tabela 2: Opis konstant materiala

\subsection{Micro-model in the commercial software}

The geometry of the finite-element model (a micromodel) of the periodically repeated volume (a unit cell) of the unidirectional fiber composite material was created in Abaqus/CAE 6.14-2.

The global coordinate system ( $x y z)$ is given by the force direction $(x)$ and the direction perpendicular to the composite surface $(z)$. The local coordinate system (123) is defined by the unit-cell edges where the axis directions correspond to the fiber direction (1) and the directions perpendicular to it (Figure 7).

Assuming a uniaxial stress across the whole specimen, the behavior of the material can be simulated by loading the unit cell with the normal stress corresponding to the external tensile force $F$.

The loading force is represented by stress $\sigma_{x}$ obtained with Equation (1) and transformed to the local coordinate system using the following form:

$\left[\begin{array}{c}\sigma_{1} \\ \sigma_{2} \\ \tau_{12}\end{array}\right]=\left[\begin{array}{ccc}\cos ^{2} \theta & \sin ^{2} \theta & 2 \sin \theta \cos \theta \\ \sin ^{2} \theta & \cos ^{2} \theta & -2 \sin \theta \cos \theta \\ -\sin \theta \cos \theta & \sin \theta \cos \theta & \cos ^{2} \theta-\sin ^{2} \theta\end{array}\right] \cdot\left[\begin{array}{c}\sigma_{x} \\ 0 \\ 0\end{array}\right]$

where $\theta$ is the angle of rotation between the local and global coordinate systems, e.g., between the fiber direction and force direction in the experiment. ${ }^{1,2}$

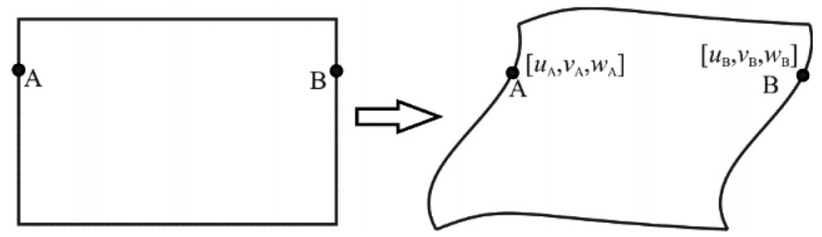

Figure 7: Equivalently deformed opposite boundaries of a heterogeneous unit cell

Slika 7: Ekvivalentno deformirani nasprotni meji heterogene enotne celice 
The results of the finite-element analysis (strains) are transformed back to the global coordinate system using the following form: ${ }^{5}$

$\left[\begin{array}{c}\varepsilon_{x} \\ \varepsilon_{y} \\ \gamma_{x y}\end{array}\right]=\left[\begin{array}{ccc}\cos ^{2} \theta & \sin ^{2} \theta & -\sin \theta \cos \theta \\ \sin ^{2} \theta & \cos ^{2} \theta & \sin \theta \cos \theta \\ 2 \sin \theta \cos \theta & -2 \sin \theta \cos \theta & \cos ^{2} \theta-\sin ^{2} \theta\end{array}\right]\left[\begin{array}{c}\varepsilon_{1} \\ \varepsilon_{2} \\ \gamma_{12}\end{array}\right]$

The unit cell must also follow the periodic boundary conditions: ${ }^{5-7}$

$$
\begin{aligned}
& \Delta u=u_{B}-u_{A} \\
& \Delta v=v_{B}-v_{A} \\
& \Delta w=w_{B}-w_{A}
\end{aligned}
$$

where $\Delta u, \Delta v$ and $\Delta w$ are the translation differences of the opposing pair of nodes in directions 1,2 and 3 , respectively. These differences must remain constant for all the pairs of the corresponding nodes on opposite sides. $^{5}$

The periodical boundary conditions were implemented in Abaqus/CAE 6.14-2 using equation constraints.

\section{ASSYMPTOTIC HOMOGENIZATION}

The two-scale asymptotic homogenization method is used to identify the material parameters of the periodic composite structure. The linear elastic medium (occupying domain $\Omega$ ) whose microstructure can be represented by a periodic (representative) volume element associated with region $Y$ and consists of the matrix part $Y_{\mathrm{m}}$ and fibers $Y_{\mathrm{f}}$ (Figure 8). Using the standard method of asymptotic expansion ${ }^{8}$ applied to the linear elastic problem, we get a microscopic equation formulated in terms of the characteristic response function and a macroscopic equation that involves the homogenized elasticity parameters. ${ }^{6,8}$

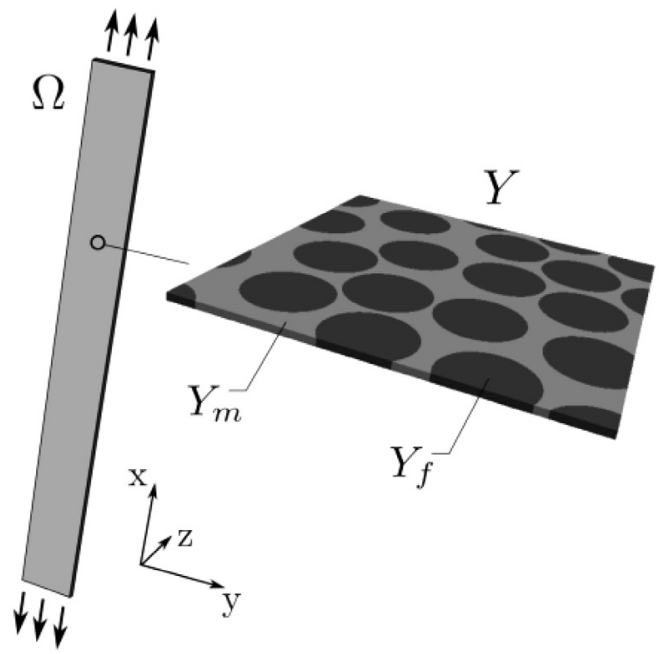

Figure 8: Macroscopic domain $\Omega$ and microscopic domain $Y$ (representative volume element) consisting of fibers $Y_{\mathrm{f}}$ and matrix $Y_{\mathrm{m}}$ Slika 8: Makroskopska domena $\Omega$ in mikroskopska domena $Y$ (reprezentativni volumski element), ki sestoji iz vlaken $Y_{\mathrm{f}}$ in osnove $Y_{\mathrm{m}}$
The problem at the microscopic level can be formulated to find the characteristic response function $\chi^{r s} \in H_{\#}(Y)$ so that:

$$
\begin{aligned}
& \int_{Y} D_{i j k l} \varepsilon_{k l}^{y}\left(\chi^{r s}\right) \varepsilon_{i j}^{y}(\omega) \mathrm{d} Y= \\
& \int_{Y} D_{i j k l} \varepsilon_{k l}^{y}\left(\Pi^{r s}\right) \varepsilon_{i j}^{y}(\omega) \mathrm{d} Y \forall \omega \text { in } H_{\#}(Y)
\end{aligned}
$$

where $\varepsilon^{y}(\cdot)$ is the linear strain tensor with respect to the microscopic coordinate $y, \Pi_{i}^{r s}=y_{s} \delta_{r i}, H_{\#}(Y)$ is the set of $Y$-periodic functions with the zero average value in $Y$. The elasticity tensor $\mathrm{D}=\mathrm{S}^{-1}$ is defined as:

$$
\begin{aligned}
& D=D(y)= \\
& =\left\{\begin{array}{l}
D^{f} \text { in } Y_{f} \text { (transvers. isotropic fibers) } \\
D^{m} \text { in } Y^{m} \text { (isotropic matrix) }
\end{array}\right.
\end{aligned}
$$

The solution of the microscopic equation, which has to be solved with the periodic boundary conditions, is used to evaluate the homogenized elasticity tensor:

$$
D_{i j k l}^{H}=\frac{1}{|Y|} \int_{Y} D_{p q r s} \varepsilon_{r s}^{y}\left(\Pi^{k l}-\chi^{k l}\right) \varepsilon_{p q}^{y}\left(\Pi^{i j}-\chi^{i j}\right) \mathrm{d} Y
$$

The homogenized (macroscopic) elasticity problem can be expressed with Equation (12):

$$
\int_{Y} D_{i j k l}^{H} \varepsilon_{k l}^{x}\left(\mathbf{u}^{0}\right) \varepsilon_{i j}^{y}\left(\mathbf{v}^{0}\right) \mathrm{d} Y=\int_{\Gamma t} v_{i}^{0} t_{i} \mathrm{~d} \Gamma
$$

which is solved for the unknown macroscopic displacement field $u^{0} \in H_{0}(\Omega)$. The macroscopic linear strain tensor is denoted by $\varepsilon^{x}(\cdot)$ and $H_{0}(\Omega)$ is the set of admissible displacements with a zero value at a boundary where the Dirichlet conditions are imposed.

The homogenization procedure, i.e., the computation of the microscopic and macroscopic equations, is embedded in an optimization loop in order to find the material parameters of the components constituting the composite structure. The optimization module of SciPy (Python library for scientific computing) ${ }^{10}$ and the Python-based finite-element solver $\mathrm{SfePy}^{9}$ for the numerical solution of the optimization problem are used.

\section{COMPARISON OF THE RESULTS}

The identified material parameters obtained using both homogenization approaches are in Table 3.

Table 3: Identified material parameters

Tabela 3: Opredeljeni parametri materiala

\begin{tabular}{|c|c|c|c|}
\hline Parameter & Unit & Commercial & Asymptotic \\
\hline \multicolumn{4}{|c|}{ Fibers } \\
\hline$E_{1}$ & $(\mathrm{GPa})$ & 165.99 & 162.55 \\
\hline$E_{2}$ & $(\mathrm{GPa})$ & 16.13 & 18.52 \\
\hline$v_{12}$ & $(-)$ & 0.18 & 0.16 \\
\hline$G_{12}$ & $(\mathrm{GPa})$ & 44.86 & 45.65 \\
\hline \multicolumn{4}{|c|}{ Matrix } \\
\hline$E_{\mathrm{m}}$ & $(\mathrm{GPa})$ & 3.28 & 3.21 \\
\hline$v_{\mathrm{m}}$ & $(-)$ & 0.43 & 0.39 \\
\hline
\end{tabular}




\section{H. SRBOVÁ: COMPARISON OF HOMOGENIZATION APPROACHES USED FOR THE IDENTIFICATION ...}

Poisson's ratio in plane 23 was considered to be constant, $v_{23}=0.4$. Both methodologies converged to similar values of the identified parameters.

\section{CONCLUSION}

Both methodologies provide comparable results. The asymptotic homogenization implemented in SfePy exhibits a less time-consuming performance taking into account the whole process of the calculation and preand post-processing of the results in each optimization design. Both approaches provide a possibility for an inverse process, calculating the stress distribution at the microscopic level using the macroscopic stress distribution. Nevertheless, commercial software Abaqus 6.14-2 with its ability to apply user subroutines provides (at the present state) a wider range of possibilities for more complicated constitutive relations (e.g., nonlinear elasticity, plasticity, damage).

\section{Acknowledgement}

This publication was supported by the project LO1506 of the Czach Ministry of Education, Youth and Sports.

\section{REFERENCES}

${ }^{1}$ T. Kroupa, V. Laš, R. Zemčík, Improved nonlinear stress-strain relation for carbon-epoxy composites and identification of material parameters, Journal of Composite Materials, 45 (2011) 9, 1045-1057, doi:10.1177/0021998310380285

${ }^{2}$ V. Laš, R. Zemčík, Progressive Damage of Unidirectional Composite Panels, Journal of Composite Materials, 42 (2008) 1, 25-44, doi:10.1177/0021998307086187
${ }^{3}$ R. Zemčík, R. Kottner, V. Laš, T. Plundrich, Identification of material properties of quasi-unidirectional carbon-epoxy composite using modal analysis, Mater. Tehnol., 43 (2009) 5, 257-260

${ }^{4}$ S. Ogihara, K. L. Reifsnider, Characterization of Nonlinear Behavior in Woven Composite Laminates, Applied composite materials, 9 (2011), 249-263, doi:10.1023/A:1016069220255

${ }^{5}$ H. Srbová, T. Kroupa, R. Zemčík, Identification of the initial failure and damage of substituents of a unidirectional fiber-reinforced composite using a micromodel, Mater. Tehnol., 48 (2014) 4, 549-553

${ }^{6}$ J. Pinho Da-Cruz, J. A. Oliveira, F. Teixeira-Dias, Asymptotic homogenisation in linear elasticity, Part I: Mathematical formulation and finite element modelling, Computational Materials Science, 45 (2009), 1073-1080, doi:10.1016/j.commatsci.2009.02.025

${ }^{7}$ J. Pinho Da-Cruz, J. A. Oliveira, F. Teixeira-Dias, Asymptotic homogenisation in linear elasticity, Part II: Finite element procedures and multiscale applications, Computational Materials Science, 45 (2009), 1081-1096, doi:10.1016/j.commatsci.2009.01.027

${ }^{8}$ D. Cioranescu, P. Donato, An Introduction to Homogenization, Oxford Lecture Series in Mathematics and its Applications 17, Oxford University Press, 1999

${ }^{9}$ R. Cimrman, SfePy - Write Your Own FE Application, Proceedings of the 6th European Conference on Python in Science (EuroSciPy 2013), (2014), 65-70, http://arxiv.org/abs/1404.6391

${ }^{10}$ E. Jones, T. E. Oliphant, P. Peterson et al., SciPy: Open source scientific tools for Python, http://www.scipy.org

${ }^{11}$ K. J. Bathe, Finite element procedures, Prentice Hall, Upper Saddle River, New Jersey 07458, USA, 2007

${ }^{12}$ J. S. Arora, Introduction to Optimum Design, Elsevier, 2012

${ }^{13}$ B. D. Lubachevsky, How to Simulate Billiards and Similar Systems, Journal of Computational Physics, 94 (1991) 2, 255-283, doi:10.1016/0021-9991(91)90222-7

${ }^{14}$ H. A. Meier, E. Kuh, P. Steinmann, A Note on the Generation of Periodic Granular Microstructures Based on Grain Size Distributions, International Journal for Numerical and Analytical Methods in Geomechanics, 32 (2008), 509-522, doi:10.1002/nag.635 